\title{
Social cohesion and social capital: Possible implications for the common good
}

\author{
Author: \\ Anita Cloete $^{1}$ \\ Affiliation: \\ ${ }^{1}$ Department Practical \\ Theology and Missiology, \\ University of Stellenbosch, \\ South Africa \\ Correspondence to: \\ Anita Cloete \\ Email: \\ acloete@sun.ac.za \\ Postal address: \\ 171 Dorp Street, \\ Stellenbosch 7600 , \\ South Africa \\ Dates: \\ Received: 13 Feb. 2014 \\ Accepted: 10 May 2014 \\ Published: 20 Aug. 2014 \\ How to cite this article: \\ Cloete, A., 2014, 'Social \\ cohesion and social capital: \\ Possible implications for the \\ common good', Verbum et \\ Ecclesia 35(3), Art. \#1331, \\ 6 pages. $h t t p: / / d x . d o i$. \\ org/10.4102/ve.v35i3.1331

\section{Copyright:} \\ (C) 2014. The Authors. \\ Licensee: AOSIS \\ OpenJournals. This work \\ is licensed under the \\ Creative Commons \\ Attribution License.
}

Read online:
The main objective of the article is to identify the possible implications of social cohesion and social capital for the common good. In order to reach this overarching aim the following structure will be utilised. The first part explores the conceptual understanding of social cohesion and social capital in order to establish how these concepts are related and how they could possibly inform each other. The contextual nature of social cohesion and social capital is briefly reflected upon, with specific reference to the South African context. The contribution of religious capital in the formation of social capital is explored in the last section of the article. The article could be viewed as mainly conceptual and explorative in nature in order to draw some conclusions about the common good of social capital and social cohesion.

Intradisciplinary and/or interdisciplinary implications: This article contributes to the interdisciplinary discourse on social cohesion with specific reference to the role of congregations. It provides a critical reflection on the role of congregations with regard to bonding and bridging social capital. The contextual nature of social cohesion is also addressed with specific reference to South Africa.

\section{Introduction}

Social cohesion is a well-known concept today, although there is no conceptual clarity on what it means. In the light thereof the first section offers a conceptual overview of social cohesion and social capital. From this discussion it is evident that social cohesion and social capital are interdependent and that context plays a significant role in the formation thereof. Therefore the question about the contextual aspects of social cohesion is reflected upon with specific reference to South Africa. Research on social capital and social cohesion is mostly done in sociology, anthropology and political science, but it is argued that religion can also make a valuable contribution. The final section of the article therefore critically reflects on the role of religious social capital through congregations in the formation of social cohesion.

\section{Social cohesion}

Social cohesion is simply referred to by some as 'the glue that holds society together' (Janmaat 2011:61) or put differently 'the property that keeps society from falling apart' (Janmaat 2011:63). However, Janmaat (2011:62) is of the opinion that too many scholars provide a rather idealised and utopian understanding of the term like the definition by Chan and Chan (2006), who define social cohesion as:

a state of affairs concerning both the vertical and horizontal interactions amongst members of society as characterized by a set of attitudes and norms that include trust, a sense of belonging and the willingness to participate and help, as well as their behavioural manifestations. (p. 290)

The definitions provided for social cohesion do not seem to differ significantly from those of social capital. The Organisation for Economic Co-operation and Development (OECD 2011:53) however warns against the narrow understanding of social cohesion as social capital and emphasises that it is a broad concept that covers several dimensions at once, like a sense of belonging, active participation, trust, exclusion and mobility. A comprehensive description of a cohesive society is offered as one that 'works towards the well-being of all the members, fights exclusion and marginalisation, creates a sense of belonging, promotes trust and offers members the opportunity of upward social mobility' (OECD 2011:51).

Oxoby (2009:1136), with reference to Dayton-Johnson (2003) alludes to a possible difference and link between social cohesion and social capital when presenting the following definitions: 'Social capital is an individual's sacrifices (time, effort, and consumption) made in an effort to co-operate with others', whilst social cohesion on the other hand refers to 'a characteristic of 
society which depends on the accumulated social capital'. The difference between social capital and social cohesion as pointed out by the OECD (2011:53) concurs with the previous definition where social capital refers to a group of individuals whilst social cohesion includes the entire society. In these distinctions it seems that social cohesion is only possible where there is social capital present or available, in other words, social capital seems to be a prerequisite for social cohesion. Therefore, the lack of social cohesion would point to a lack of social capital. In order to give a better account of social capital as an integral component of social cohesion, the following section will focus on a conceptual discussion of social capital.

\section{Social capital}

It is reasonable to argue that social capital is one of the key elements of social cohesion. In view thereof I found it necessary to give some indicators of what is meant with the concept social capital, as well as the challenges with regard to it, specifically from an academic perspective. The following components of trust, social networks, norms and reciprocity seem to be prominent in social capital formation. In the following section I shall explain the concept of social capital according to these core elements. The concept of social capital is studied in the fields of sociology and political science, and research on social capital in the social sciences has been largely influenced by the work of Pierre Bourdieu (1985), James Coleman $(1988,1990)$ and Robert Putnam $(1993,2000)$.

Bourdieu and Coleman 'define social capital as a range of resources available to individuals thanks to their participation in social networks' (cited in Herreros 2004:6). In the same vein Bartkus and Davis (2009:2) define social capital as a representation of the resources that arise from relationships and which could assist individuals and the collective to reach their goals in working towards the common good. With regard to the definitions of social capital two approaches are highlighted by Bartkus and Davis (2009:4). The functional approach is derived from the work of Putnam (1993:163) who describes social capital as the 'features of social organizations, such as trust, norms and networks that can improve the efficiency of society by facilitating coordinating actions'. The second approach, namely the descriptive approach, comes from the work of Nahapiet and Ghoshal (1998:243), who describe social capital as the sum of actual and potential resources embedded within, available through and derived from the network of relationships possessed by individuals or social unit'. Bartkus and Davis (2009:4) observe that scholars tend to emphasise the resources or effects of social capital in defining social capital.

There are at least two components of social capital that could be distinguished, but not separated, namely structure and content (Bartkus \& Davis 2009:2). The structural aspect refers to formalised patterns of connections, like network configurations or participation in voluntary organisations, whilst the content dimension includes the relational aspects and refers to human assets in these network relationships. The relational dimensions further include the quality of the individual connections which make up the broader network and also focus on trust, fairness and social norms, which lead to obligation and expectation in order to create reciprocity (Lewicki \& Brinsfield 2009:277). Information and trust are some of the resources that could be derived from participation in social networks. However, this does not mean social capital equals trust or networks, but is rather related to the obligation of reciprocity that could be derived from the relations of trust and the information gained from the participation in social networks (Herreros 2004:7). Herreros (2004:9) does not see trust as social capital, but rather views trust as having an intermediary role between members that participate in social networks and the generation of social capital. Information, on the other hand, is viewed as a by-product derived from the participation in social networks (Herreros 2004:15). Coleman (1990:310), however, argues that the informative potential of social networks is a form of social capital. Bartkus and Davis (2009:5) hold the view that networks can reinforce trustworthy behaviour, whilst norms as rules of acceptable behaviour provide reasons for members of a community to interact in a trustworthy manner. Norms also provide mechanisms to evaluate behaviour as good or bad and to punish or reward behaviour accordingly.

I would like to highlight at least two characteristics of social capital. Firstly, social capital is viewed as public good and is never the private property of anyone who benefits from it. Social capital therefore has some of the features of a public good which means that one cannot exclude individuals from benefiting from it (Herreros 2004:19). Secondly, social capital is viewed as human-made capital and not natural capital. Natural capital refers to nature's resources like the oceans, atmosphere and biodiversity which were not created by humankind. Human-made capital on the other hand is what is created by humankind with time and effort in the hope that it will increase benefits in the future. Human-made capital could be divided into three types, namely physical capital, human capital and social capital. An interesting feature of social capital as a type of human-made capital is that it can grow with appropriate use, in other words, it becomes more and better when it is used (Grootaert \& Bastelaer 2002:4). At the same time if there is no reciprocity in the use of social capital it could be easily destroyed and is far more difficult to rebuild than physical capital. Although capital is defined as a set of assets that could generate benefits in the future, at least two of the shared characteristics of human-made capital point to the negative effect capital can have, namely that there is no guarantee that any type of capital will produce future benefits and that capital can also have a negative instead of a positive effect (Ostrom 2009:21-22).

What seems evident in the literature defining social capital is that it is not an individual endeavour, but the sum of the efforts of individuals that participate together in any form of social network to create or build social capital that results in 
public good or common good, even for those who did not participate. Trust is one of the core elements in this process which enables people to expect good from others (reciprocity) and to act on behalf of others in order to create a better future for all. Information also plays a vital role since the more relevant information people have about each other, the more eager they are to participate or not, the more trust or distrust is created, confirmed or destroyed. The public good feature of social capital could be viewed as a positive attribute, but at the same time it could lead to under investment in social capital as people do not receive all the benefits from it, but have to share it with others, even with those who did not participate or contribute (Putnam 2000:20). In order to create trust and guarantee reciprocity, norms and values are needed to guide the process of participation in networks. It seems that people with values like honesty, trustworthiness, integrity, who care for their fellow humans, are likely to create social capital that could lead to the formation of public good.

One of the difficulties associated with social capital is the variety of definitions that exist, which makes it almost everything and close to nothing specific in the end (Grootaert \& Bastelaer 2002:5). It is also difficult to measure social capital empirically (Grootaert \& Bastelaer 2002:6). However, that does not imply that it does not exist. Janmaat (2011:61) phrases this challenge in the question as to whether the proposed understanding of 'social cohesion refers to an actual real-life phenomenon or merely to a hypothetical state of affairs'. Despite these difficulties that need to be taken into account when we work with these concepts and their implications for everyday life, I found the descriptions helpful in describing social interaction and the benefits and dangers thereof for the common good. In the rest of the article I will refer to social capital and social cohesion interchangeably, but with the understanding that social capital and social cohesion are closely related but not exactly the same.

\section{Does context matter in the formation of social cohesion?}

Theoretically social cohesion indeed sounds astounding and describes an even better social reality, but does that simply imply that people network across cultures, class, economic and religious boundaries? I think it is of the utmost importance to pose the question about the relationship of context and social cohesion. From the theoretical perspective social cohesion could be viewed as a universal phenomenon, but the question of context and social cohesion highlights the regional or local existence of the phenomenon. It seems that certain conditions are assumed in the formation of social cohesion, for example, that people are trustworthy, have integrity, care for each other, and are eager and open to participate in networks together. Janmaat (2011:62) tackles more or less the same issue when posing the question: '... are societies characterized by value consensus also more equal, more trusting, more civically minded and less criminal?' The underlying reasoning behind this question is that in an equal society where all people have access to work, education, and health services, the formation of social cohesion is more likely to take place. In other words, these conditions could be viewed as more conducive to social cohesion formation or 'interlinked constituents' of social cohesion (Janmaat 2011:64).

Portes and Vickstrom (2011:473) allude to the contextual nature of social cohesion when they explain that cohesion in a modern world does not rely on close networks in a community (social capital), but rather on organic solidarity on the basis of universalistic rules. In a modern society 'trust does not depend on mutual knowledge, but universal rules and the capacity of institutions to compel their observance'. Portes and Vickstrom (2011:476) conclude in this regard that many of the benefits of communitarian social capital are correlates, rather than consequences and are dependent on more basic structural factors of which inequality, level of education of the population and its ethnic-racial composition are the most important. This implies that good governance is directly linked to social cohesion as it increases trust and tolerance and acceptance of diversity. Chidester, Dexter and James (2003:324) emphasise the contextual nature of social capital and describe it in different spheres as follows: in government (as social trust), in labour (as social livelihood), in business (as social responsibility) and in community (as social kinship).

In a country like South Africa where inequality, unemployment and poverty divide people into different socioeconomic groups, rich and poor, where religion still divides people along racial lines, what will the process of social capital formation look like? Do people across these boundaries have the same vision and needs in order to participate in networks together and build social capital and so improve or form social cohesion? Are they on equal ground in order that all participants' contributions are valued and taken seriously? Is the South African context not more conducive for negative networking, that is, against each other? Gavin Bradshaw (2009:186-191) lists the challenges that threaten social cohesion in South Africa as follows: lack of service delivery, fault-lines of race and identity, neo-liberal macro-economic policies, high levels of crime, polarised opinions on salient issues, lack of interracial contact, resolution of the Truth and Reconciliation Commission (TRC), land reform, farm murders and emigration. Despite these realities present, Chidester et al. (2003:323) state '... South Africa has embraced the ideal of social cohesion'. They admit (Chidester et al. 2003:334), however, that the benefits of social capital cannot just be assumed and are of the opinion that the benefits that could be derived from shared norms, mutual trust and social networks need some agency. Social capital from a value perspective could be viewed as sacred. It is in the light of the sacredness of the values and norms assumed in social capital formation that I turn the focus to the role of religion in social capital, in the last section of the article. 


\section{Religion and social cohesion}

The focus on religion and social capital could be associated with questions like whether social renewal is possible without moral renewal, or does religion matter in the public sphere? This focus on religion by no means views religion as the ultimate uniting factor in social cohesion, as I am well aware of the dividing power of religion. Putnam (2000:301) for instance describes the dark side of social capital formation by religious involvement as 'secretarian social capital' which leads to intolerance, especially in fundamentalist churches or groups. The saddening fact that religion seems to divide people along racial and economic lines specifically in South Africa, is another example of how religious social capital can hamper social cohesion. However, I see religion as an important partner in social issues and public life and therefore also in the formation of social capital and social cohesion. In the words of Preduca (2011:129): 'Religious moral traditions have proved their fitness in enhancing community building. Religion plays an important role in sustaining social cohesion and answers personal needs.' Bramadat (2005:209) is also of the opinion that religious traditions are the moral, social and spiritual bedrock of communities and individuals and therefore it would be irresponsible to assume that traditions have nothing to contribute to public issues and social capital.

Congregations are good examples of how religion could be of value in social capital formation where people gather and build networks in a specific community. The church is one of the public institutions that sees and understands itself explicitly as a community (Coleman 2003:36). Although in the technology era, where face-to-face contact is declining, there are still quite a lot of people belonging to and attending congregations in South Africa. Joining congregations is not merely an act of finding spiritual meaning, but also provides a social context where people meet and form social networks conducive to social capital formation (Cnaan, Boddie \& Yancey 2003:21). This togetherness is likely to enhance the possibility that members will internalise the norms of the group and share in activities with other members (bonding social capital) and most congregations have opportunities for members to reach out to people outside their religious groups (bridging social capital) (Cnaan et al. 2003:26). Coleman (2003:36-40) warns that there are also limits with regard to religious social capital formed by congregations. The first aspect is that of horizontal and vertical religious authority. Horizontal religious authority which is characterised by hierarchical leadership may lead to more passive members, whereas vertical religious authority may lead to more active members. Small churches seem to be better positioned for social capital formation than mega churches. Groups in a congregation could form cliques which could lead to social capital becoming frozen within one part, or in separate pockets of cliques within the congregation. An overemphasis on congregation as the only unit of religious social capital formation could be misleading since the efforts of congregations are just too limited and should work with other para-church organisations in order to have a greater public relevance.
Research has shown that religious institutional involvement has been related to multiple dimension of health, probably because of the normative structure and symbolic vocal point these institutions provide. This implies that even bonding capital that is mostly associated with those inside religious institutions could have a 'spillover' effect into the broader community (Mason, Schmidt \& Mennis 2012:229-231). Despite the potential negative effect of bonding social capital through congregations, it is also possible that bonding capital may help members to gather skills and insight to reach out to others outside their religion and racial group. Congregants internalise the values provided by bonding religious capital that inspires them to become involved in the broader society. Todd and Allen (2011:235) are of the opinion that ' $[c]$ ongregations provide a space for individuals to participate in congregationally sponsored social justice activities, linking individuals into larger community based social justice participation'.

It could therefore be argued that bonding capital in religious institutions could lead to bridging capital on individual and congregational levels. Mason et al. (2012:229) explored the religious social capital of the multiple dimensions of religiosity, namely private religion (referring to intrapersonal aspects of religious practice), social religion (referring to public behavioural aspects of religious practice) and perceived religiosity (referring to congregants' feelings of general and specific support), as protective factor for substance abuse (Mason et al. 2012:230). Their findings interestingly indicate that proximity to religious institutions serves as preventive factor, because their presence is perceived to fostering stability in communities.

Furthermore, social religiosity provides relationship, peer and adult modelling and coping resources that are of importance to prevent substance abuse (Mason et al. 2012:234). Similarly research by Allen (2010) indicates that religious institutions can provide bonding and bridging capital in the lives of immigrants. Bonding religious social capital reaffirms their national identities and allows them to practice familiar rituals as religious institutions serve as community centres providing in their social and spiritual needs. Bridging religious capital conceptually and practically connects them to the wider society, by helping them to diversity and strengthening their social networks (Allen 2010:1050-1052). Todd and Allen (2011:222) also claim that religious institutions have the potential to provide a mediating structure for social justice engagement for the common good of the larger community. Despite research pointing to the possibility that bonding religious capital could lead to bridging capital in congregations it still is a very fragile process.

Therefore, it is important to respond to the question: how could religious social capital be fostered through congregations in order to enhance social cohesion in society? It is beyond the scope of this article to give an adequate response, but I would like to point out that at least two things 
seem to be important in this regard. Leadership seems to be of utmost importance. I agree with Brown, Kaiser and Daniels (2010:10) that spiritual leaders of congregations need to be more politically conscious in order to facilitate specifically racial divisions and foster bridging religious social capital. Brown et al. (2010) conclude that:

$[C]$ lergy and laity that engage in political discourse within houses of worship are able to bridge social capital in a manner that yields recognition of common interest among groups of diverse racial backgrounds. (p. 12)

Thomas (2001:1) in the same vein argues for a political spirituality that may seem like 'a startling contradiction in terms', but is essential in the Christian life. This political spirituality encourages participation in the public sphere and does not see it as optional, but as the church's participation in God's mission in the whole world. One way that leadership could foster religious bridging capital is by cultivating a climate of openness and collaboration with other congregations (Todd \& Allen 2011:234). Congregational partnerships are therefore seen as key in order to enhance social cohesion through congregations. Congregational partnerships could be expanded to networking with a wider network that includes other organisations and government. Congregational partnerships however prove not to be easy for congregations, despite the fact that they face similar challenges and share the same vision (Cloete 2009:88). Nel (2009:3) agrees that bridging religious social capital could be formed through ecumenical bonds with other believers from other denominations and cultural backgrounds. He however formulates the challenge it poses to leadership as follows: 'This asks for special demands from leadership as it often requires people to be taken outside their comfort zones' (Nel 2009:3). Bridging religious social capital could lead to the transformation of congregations, as hospitality to neighbours becomes important to reach beyond our known boundaries. In that sense bridging religious capital by congregations is not only of importance for the common good, but it also confirms the mission for which the church exists.

Lastly I would like to highlight the value of Christian practices as a means of fostering bonding and bridging religious capital that could enhance social cohesion. Although Christian practices are merely human activities and not holy in themselves, participating in these practices put us in a position where we recognise and participate in the work of God's grace in the world (Dykstra 2005:41). In other words Christian practices like prayer, confession, worshipping God together (Dykstra 2005:42-43) are ordinary ways in which congregations respond to what God has done for us through Jesus Christ. Christian practices are '... habits, disciplines and patterns of life through which Christian seek communion with Christ and solidarity with others' (Yaconelli 2001:155). Through Christian practices, congregants confess that God is with them and in God's presence they have become aware of the needs in the world. Therefore Yaconelli (2001:162) claims that Christian practices are only made complete in service. Dykstra (2005:60-61) identifies at least two transformations that take place when these practices occur, namely that we start seeing each other as fellow creatures and through hospitality the stranger becomes a neighbour. Christian practices should therefore lead Christians beyond their comfort zone into the world, to serve. Therefore Christian practices could assist congregations to move from bonding religious capital to bridging religious capital for the common good that could enhance social cohesion.

\section{Conclusion}

Although a variety of definitions exist on social capital the core elements seem to be the networks, trust, norms and reciprocity that exist between individuals and groups. Social cohesion could be viewed as the positive outcome of social capital formation for a community that in return could lead to more social capital formation. It is clear that social capital formation is a very fragile process as it could easily be destroyed, but could take years to build. Critics highlight the fact that social capital 'cuts both ways' as it has positive and negative effects. Reflection on the contextual nature of social cohesion - specifically in South Africa - produces more questions than answers as to what social capital formation could be like despite the huge challenges the country faces. Literature suggests that social capital formation rests on norms and values that guide the process and it is argued that religious capital, specifically through congregations, could give agency to these elements. The dangers and limitations of religious social capital of congregations specifically (congregations in general) are highlighted, and leadership and political spirituality is suggested as two of the important elements of forming religious social capital today. Although congregations are mostly associated only with bonding capital, research increasingly indicates that this bonding capital could lead to bridging social capital. I propose that congregational partnerships and networking with other organisations and even government could enhance the possibility of bridging social capital. Christian practices that are mostly associated with bonding social capital are argued to be completed only in the services to those outside our congregation, those that are seen as the enemy, different and unknown. Christian practice should open our eyes to see others as fellow creatures, our neighbour whom we should serve in love. Hospitality is proposed to be given as the means to move from bonding religious capital to bridging religious capital, participating in the mission of God in the world.

\section{Acknowledgements Competing interests}

The author declares that she has no financial or personal relationship(s) that may have inappropriately influenced her in writing this article.

\section{References}

Allen, R., 2010, 'The bonding and bridging roles of religious institutions for refugees in a non-gateway context', Ethnic and Racial Studies 33(6), 1049-1068.http://dx.doi. org/10.1080/01419870903118130 
Bartkus, V.O. \& Davis, J.H., 2009, Social capital: Reaching out, reaching in, Edward Elgar Publishing, Northampton, MA. http://dx.doi.org/10.4337/9781848445963

Bourdieu, P., 1985, 'The forms of capital', in J.G. Richardson (ed.), Handbook of theory and research for sociology of education, pp. 241-260, Greenwood, New York.

Bradshaw, G., 2009, 'Social cohesion in a post-conflict context: Case study of South Africa 12 years on', International Social Science Journal 192, 183-195.

Bramadat, P.A., 2005, 'Religion, social capital, and "The day that changed the world", Journal of International Migration and Integration 69(2), 201-217. http://dx.doi. org/10.1007/s12134-005-1010-9

Brown, R.K., Kaiser, A. \& Daniels, W., 2010, 'Religion and the interracial/ethnic common good', Journal of Religion and Society 12, 1-17.

Chan, J.T.H. \& Chan, E., 2006, 'Reconsidering social cohesion: Developing a definition and analytic framework for empirical research', Social Indicators Research 75 273-302. http://dx.doi.org/10.1007/s11205-005-2118-1

Chidester, D., Dexter, P. \& James, W., 2003, 'Conclusion: Social Cohesion in South Africa', in D. Chidester, P. Dexter \& W. James (eds.), What holds us together? Social cohesion in South Africa, pp. 323-338, HSRC Press, Cape Town.

Cloete, A., 2009, 'Exploring unemployment's challenges to the church's mission today', in H.J.C. Pieterse \& C.H. Thesnaar (eds.), A faithful witness: Essays in honour of Malan Nel, pp. 81-92, Bible Media, Wellington.

Cnaan, R.A., Boddie, S.C. \& Yancey, G.I., 2003, 'Bowling alone but serving together: The congregational norm of community involvement', in C. Smith (ed.), Religion as social capital: Producing the common good, pp. 19-32, Baylor University Press, Waco, TX.

Coleman, J.S., 1988, 'Social capital in the creation of human capital', American Journa of Sociology 94, 95-120. http://dx.doi.org/10.1086/228943

Coleman, J.S., 1990, Foundations of social theory, Harvard University Press, Cambridge.

Coleman, J.S., 2003, 'Religious social capital: Its nature, social location and limits', in C. Smith (ed.), Religion as social capital: Producing the common good, pp. 33-48, Baylor University Press, Waco, TX.

Dayton-Johnson, J., 2003, 'Knitted warmth: The simple analytics of social cohesion', Journal of Socio-Economics 32(6), 632-645. http://dx.doi.org/10.1016/j. socec.2003.10.002

Dykstra, C., 2005, Growing in the life of faith: Education and christian practices, Westminster John Knox Press, Louisville, KY.

Grootaert, C. \& Bastelaer, T., 2002, 'Introduction and overview', in C. Grootaer \& T. Bastelaer (eds.), The role of social capital in development: An empirical assessment, pp. 1-18, University Press, Cambridge.

Herreros, F., 2004, The problem of forming social capital: Why trust?, Palgrave Macmillian, Houndsmill. http://dx.doi.org/10.1057/9781403978806
Janmaat, J.G., 2011, 'Social cohesion as real-life phenomenon: Assessing the explanatory power of the universalist and particularist perspectives', Socia Indicators Research 100, 61-83. http://dx.doi.org/10.1007/s11205-010-9604-9

Lewicki, R.J. \& Brinsfield, C.T., 2009, 'Trust and distrust and building social capital', in V.O. Bartkus \& J.H. Davis (eds.), Social capital: Reaching out, reaching in, pp. 275-303, Edward Elgar Publishing Limited, Northampton, MA. http://dx.doi. 275-303, Edward Elgar Publishing
org $/ 10.4337 / 9781848445963.00022$

Mason, M.J., Schmidt, C. \& Mennis, J., 2012, 'Dimensions of religiosity and access to religious social capital: Correlates with substance use among urban adolescents', Journal of Primary Prevention 33, 229-237. http://dx.doi.org/10.1007/s10935-012Journal

Nahapiet, J. \& Ghosal, S., 1998, 'Social capital, intellectual capital and the organizational advantage', Academy of Management Review 23(2), 242-266.

Nel, I., 2009, 'Leaderships in acts through a social capital lens', Verbum et Ecclesia 30(2), $1-7$.

Organistaion for Economic Co-operation and development (OECD), 2011, 'Perspectives on Global Development 2012: Social cohesion in a shifting world', pp. 1-63, viewed 21 March 2013, from http://dx.doi.org./10/1787/persp_glob_dev_2012en

Ostrom, E., 2009, 'What is social capital?', in V.O. Bartkus \& J.H. Davis (eds.), Social capital: Reaching out, reaching in, pp. 17-38, Edward Elgar Publishing, Northampton, MA. http://dx.doi.org/10.4337/9781848445963.00010

Oxoby, R., 2009, 'Understanding social inclusion, social cohesion and social capital', International Journal of Social Economics 36(12), 1133-1152. http://dx.doi. org/10.1108/03068290910996963

Portes, A. \& Vickstrom, E., 2011, 'Diversity, social capital, and cohesion', Annual Review of Sociology 37, 461-479. http://dx.doi.org/10.1146/annurev-soc-081309-150022

Preduca, G., 2011, 'Democracy, religious ethics, and human rights', Contemporary Readings in Law and Social Justice 3(1), 129-133.

Putnam, R.D., 1993, Making democracy work: Civic traditions in modern Italy, Princeton University Press, Princeton.

Putnam, R.D., 2000, Bowling alone: The collapse and revival of American community, University Press, Princeton.

Thomas, O., 2001, 'Political spirituality', Journal of Religion \& Society 3, 1-12.

Todd, N.R. \& Allen, N.E., 2011, 'Religious congregations as mediating structures for social justice: A multilevel examination', American Journal for Community Psychology 48, 222-237. http://dx.doi.org/10.1007/s10464-010-9388-8

Yaconelli, M., 2001, 'Focusing youth ministry through Christian practices', in K.C. Dean, C. Clark \& D. Rahn (eds.), Starting right: Thinking theological about youth ministry, pp. 155-166, Zondervan Publishing House, El Cajon, MI. 